Kovács István

\title{
Vezetői stílusok a hivatásos állomány szemével: laissez-faire (ráhagyó)
}

\section{Leadership Styles with the Policemen' Eyes: Laissez-faire Style}

\begin{abstract}
Absztrakt
A tanulmányban részleteiben elemzem Lewin egy vezetési stílusát (laissez-faire), majd azt egy a 2018. évben végzett "survey" felmérés eredményeivel vetem össze. A kutatás során a forráskritika, az analízis és szintézis dialektikus egysége mellett kvantitatív eszközöket is felvonultató statisztikai számítások elvégzésére volt lehetőségem, amely a korrelációs együttható, azaz a hatásfoknagyság mérésére is kiterjedt.
\end{abstract}

Kulcsszavak: vezetés- és szervezéselmélet, vezetési stílusok, rendörség, felmérés

\section{Abstract}

One of the leadership styles (laissez-faire) from Lewin were analysed in the study, which were compared with 'survey' results from the year 2018. Beyond source criticism, analysis and synthesis / could use quantitative tools, and could conduct correlation and efficiency calculations, too.

Keywords: leadership theory, leadership styles, police, survey

Tanársegéd, Nemzeti Közszolgálati Egyetem Rendészet Vezetéstudományi Tanszék, PhD - University of Public Service Faculty of Law Enforcement Department of Law Enforcement Management Theory, Police Major, Assistant Lecturer, e-mail: kovacs.istvan@uni-nke.hu, ORCID: https://orcid.org/0000-0002-7210-1981 


\section{Bevezetés}

2018-ban a rendőrség hivatásos állományából kiválasztott 50 fö részvételével egy olyan anonim alapkutatást folytattam le, amely a végrehajtói állomány szemével a vezetéstudomány elméleti téziseinek gyakorlati megvalósításáról reális képet mutat.

Az alapkutatás a rendelkezésre álló primer és szekunder források elemzésére irányult, amelynek során levéltári, múzeumi és online is elérhető adatgyüjtő tevékenységet folytattam. Nem feledkezhetünk meg arról sem, hogy az alapkutatás csak akkor teljes, ha az adatgyüjtő tevékenység mellett a forráskritika alkalmazása is megjelenik, a kohéziók mellett az (ész)érvelés is fontos szerepkörhöz jut. ${ }^{2}$ Az elméleti szakasz absztraktálható, logikai erőfelhasználást követelt meg, az analízis és szintézis dialektikus felhasználása segített abban, hogy a vizsgált témakört (lényeges tulajdonságainak, strukturális elemeinek és egyes kapcsolatainak szétválasztásával) gondolati részekre bonthassam, majd minden egyes részt - felépítés és funkcionalitás alapján - az egészhez való viszonyulása alapján feltérképezzem. Az alapkutatást követően olyan alkalmazott módszertanra volt szükségem, amely a kísérleti igényeket kielégíti (azaz minél több információ beszerzésére képes), a célkitűzések teljesítésére alkalmas (azaz az eredmények tekintetében javaslatok dolgozhatók ki), valamint a jelenség megismerésének alapjául szolgáló pilléreket lefekteti (azaz a divíziók összehasonlíthatók, a trendek minőségi és mennyiségi kontextusban leírhatók). Módszerként mindehhez kvantitatív elemzést választottam, matematikai statisztikai próbákat végeztem, különös tekintettel a Cohan- és Likert-skálán mérhető hatásfok nagyságára, a korrelációra.

E tanulmányban a kutatás egyik részszegmense, azaz a vezetési stílusokkal kapcsolatos divízió elemzése és azok eredményeinek ismertetése történik. A fentiekkel összefüggésben, hipotézisem szerint - feltételezem, hogy - a kiválasztott minta vonatkozásában a rendőri vezetésben a laissez-faire (ráhagyó) vezetési stílus nincs jelen, az nem is alkalmatos a rendőri szervek vezetésére.

Általános célom volt, hogy egy olyan tanulmány születhessen, amely a rendöri állomány vezetési stílusairól, annak mechanizmusáról reális képet mutat, továbbá egy olyan információs adatbázist hoz létre, amely a kidolgozott javaslatok megvalósíthatóságának - relevanciájának, fenntarthatóságának, megalapozottságának, életképességének - tekintetében a rendőri vezetők vezetéselméleti tudását mélyíti.

\section{Laissez-faire vezetési stílus a vezetés/irányítás kontextusában}

A vezetési stílusoknak szük és tág értelmezése ismeretes. Tágabb értelmezésén a szervezetben munkát végző emberek irányítási módját értjük, szűk értelmezésében a vezetési stílus olyan komplex jelenségnek tekinthető, amelyben a vezető által követett elvek és az alkalmazott eljárások (módszerek és igénybe vett eszközök)

Deák József: A tudomány szabadsága, politikai és hierarchikus hatások régen és ma a Belügyi Szemlében. Pécsi Határőr Tudományos Közlemények, 17. (2016), 271-276. 
együttesen kifejeződnek, és amely a vezető személyisége és a környezeti tényezők által meghatározott. ${ }^{3}$

Egy ilyen hatalmas szervezet múködését nem érthetjük meg, ha az alapvetö fogalmakat, úgymint irányítás és vezetés, nem definiáljuk, azokat nem határoljuk el egymástól.

Ha az irányítás és vezetés fogalmait definiálni szeretnénk, azt mondhatnánk, hogy az irányítás nem más, mint a teljesítmény mérése és korrekciója annak biztosítása érdekében, hogy a szervezeti célok és tervek megvalósuljanak, míg a vezetés az irányítás szakmai ellenőrzését valósítja meg. ${ }^{4}$ Ezt úgy is megfogalmazhatjuk, hogy az irányítás a „vezetés igazgatása”, a vezetés pedig az „igazgatás igazgatása”.

Hogy mindezt megértsük, 1991. szeptember 23-án az Alkotmánybíróság a 48/1991. (IX. 26.) számú AB határozatában a vezetés és irányítás fogalmának meghatározására és egymástól való elhatárolásukra rávilágított. ${ }^{5}$ Le kell szögeznünk, hogy bár az irányítás és a vezetés külön funkciókkal rendelkezik, feladatuk akkor is egységesen a szervezet eredményes müködtetésére irányul, egymás nélkül nem értelmezhető fogalmak. Elhatárolásuk alapját az irányított szervezethez való viszony és - az állami irányításban - az irányítási, illetve vezetői aktusok különböző jogi minősége képezi. Az irányító az irányított szervezeten kívül (fölötte) áll, a vezető viszont a szervezet csúcsán, de azon belül, annak részeként helyezkedik el. Az irányító az irányított szervre alapvető befolyást gyakorol. Az államszervezeten belüli irányítás esetén az irányítás közjogi jogosítványok alapján folyik. Az irányítás eszközei - ha a hatásköri szabály erröl nem rendelkezik - felölelik az állami szervezés teljes eszköztárát. A vezetés mindig az irányítás keretei között marad, az irányítás által kitüzött feladatokat hajtja végre. (Nemcsak akkor, ha az irányító és a vezetö között [szervezeti] hierarchikus alá-fölé rendeltségi viszony van, hanem akkor is, ha az irányítás végrehajtása mellett a vezetői önállóság is rendelkezésre áll.)

A vezetési stílusok leginkább ismeretes tipológiáját Lewinhoz kötik. ${ }^{6}$ E rendszerben az autokrata, ${ }^{7}$ a demokrata és a ráhagyó vezetési stílusok eredményességét, hatékonyságát és a befolyásoló szerepét egy társas attitüd alapján vizsgálták. A vezetési stílus mindig áthatja a vezetési folyamat egészét. Ez igaz a folyamat kezdőlépésére (a feladatok kitüzésének és tisztázásának, az elérendő cél és az ahhoz elvezető tevékenységek meghatározásának folyamatára), valamint a legvégső elemre (a kiadott utasítások, szabályok betartásának kontrollfeladatára) is. ${ }^{8}$

Kovács Gábor - Czuprák Ottó: A szervezetvezetés elmélete. Budapest, Dialóg Campus, 2017.

Dean Koontz: Readings in Management. McGraw-Hill, 1959.; Stafford Beer: Decision and Control. Chichester, Wiley, 1966.

5 48/1991. (IX. 26.) számú AB határozat. Elérhető: http://public.mkab.hu/dev/dontesek.nsf/0/413887D00724A32FC1257ADA00529B43?OpenDocument (A letöltés dátuma: 2017. 11. 26.)

6 Kurt Lewin - Fritz Heider - Grace Heider: Principles of Topological Psychology. New York, Mcgraw Hill, 1936.; Dragon Sándor: A rendészettudomány hatása, alkalmazása és fejlődésének lehetőségei a rendészeti szervek gyakorlati vezetésében, irányításában. Rendörségi Tanulmányok, 2. (2019), 3. 86-98.

7 Dragon Sándor: Nyilas rendvédelem - tények, tapasztalatok, következtetések. Zsidó sorsok a nyilas időszakban konferencia a kutatók éjszakáján 2019. szeptember 27., Budapest, Holokauszt Emlékközpont, 2019.

8 Kovács István: Vezetési funkciók egy helyi rendvédelmi szerv életében. Ellenőrzés, mint a kiadott szabályok, és utasítások betartásának (kontroll)feladata. Államtudományi Mühelytanulmányok, (2017), 21. 1-30. 
Egy olyan szerv, mint a rendőrség nem müködhet szigorú jogszabálybetartás, és -végrehajtás nélkül. ${ }^{9} \mathrm{~A}$ parancsuralmi és egyéni felelősségmegállapító rendszer biztosítja, hogy a vezetés- és irányításmátrix müködőképes, az állami cél elérhető, és végül az állampolgárok biztonság iránti igénye kielégítést nyerjen. A belső szabályzóként és a mindennapi múködésben egyaránt értelmezhető parancs a katonai szolgálati rend és fegyelem biztosításának legelemibb része. Hogy ez müködhet-e a ráhagyó (laissez-faire) vezetési stílussal, azt a kutatás eredményeiből megtudhatjuk.

A laissez-faire vezetési stílus úgy foglalható össze, mint a "vezetés hiánya" vagy a "leveszem a kezem rólatok" megközelítés..$^{10} \mathrm{~A}$ vezető az aktív részvételt a célok meghatározásában, az elvárások tisztázásában, a prioritások szervezésében és az érintettek bevonásában elkerüli. A vezető rendkívül passzív és inaktív is egyben, amely azt eredményezi, hogy a vezetett személy önigazgatóvá válik. ${ }^{11} \mathrm{E}$ tekintetben a parancsnoki kontroll jelenléte kizárólag szükség esetén valósul meg, annak minősége elhanyagolható. Az aktuális végrehajtói szint feladatát önállóan hajtja végre, anyagait önállóan készíti el. A munkafeladatok tekintetében az adott szint a végrehajtói hierarchia olyan magas fokán helyezkedik el, hogy - önálló vezetési jogkör gyakorlásának delegálásával - szolgálati feladat ellátása érdekében létrehozott munkacsoport vezetésével is megbízható. A tevékenysége során hozott döntéseket önállóan is meghozhatja, vezetöi kontroll nélkül. A csoportban a beosztottak egyedül vagy csoportosan döntenek, a vezető minimális mértékben vesz részt a döntésben. A vitát ráhagyja a csoportra, gyakorlatilag „nincs jelen” mint vezető. A vezető nem végez szervezést, koordinálást, nem avatkozik bele a feladatok végrehajtásába. Elmarad az ellenörző, értékelő tevékenysége is. ${ }^{12}$

Egy strukturált többszintü, a rendőrségen belüli szolgálati ágak, szolgálatok, szakszolgálatok irányítása esetén a lineáris szervezetben a laissez-faire ráhagyó vezetési stílus negatív attitüdje szükségszerüen az irányító vezetőnek a vezetési stílusában lényegesen nagyobb hatással, nagyobb arányban jelentkezik. A rendőrség egységes (tipizált szervezési állománytáblázat) állami, az erőszak monopóliumával felruházott szervezetében komplexen jelenítődik meg a bűnügy és rendészet mind szakmai, mind az erőforrás-gazdálkodást és a belső igazgatást megjelenítő strukturális rendszere. ${ }^{13}$ Ezért tér el a helyi, területi és központi szint.

\section{A kutatás eredményei}

\subsection{Személyes körülmények}

Az első blokk a kitöltők személyes körülményeinek megismerésére irányult. A felmérés e fejezetében összesen 12 kérdést tettem fel, amelyek közül mind a 12 egyszerü

9 Deák József: The Police, then Interior Review for the Forming of the Science of Law Enforcement; from its Beginning to the Change of the Political System. West Bohemian Historical Review, 4. (2014), 2. 237-254.

10 Peter Northouse: Leadership: Theory and Practice. Thousand Oaks, Sage, 2006.

11 Alice Eagly - Mary C. Johannesen-Schmidt - Marloes L. van Engen: Transformational, Transactional, and Laissez-Faire Leadership Styles: A Meta-analysis Comparing Women and Men. Psychological Bulletin, 124. (2003), 4. 569-591.

12 Kovács Gábor: A rendészeti szervekben lejátszódó folyamatok. In Horváth József - Kovács Gábor (szerk.): Rendészeti szervek vezetés- és szervezéselmélete. Nemzeti Közszolgálati Egyetem, 2014.

13 Piros Attila: Gondolatok a vezetésröl, a parancsnoki munkáról. Magyar Rendészet, 17. (2017), 4. 177-191. 
zárt láncú kérdést tartalmazott. A kérdések között e szegmensnél az életkor, a nemi identitás, valamint a legmagasabb iskolai végzettsége szerepelt. (Ugyanakkor más tárgykörök is ismertetésre kerülhetnek, de a vezetési stílusokkal összefüggésben e kérdéseknek van meghatározó jelentőségük.) A fentiekből az alábbi eredmények születtek.

\subsection{1. Életkor}

A feltett kérdés a résztvevő személyes életkorának megismerésére irányult. (A résztvevőnek a felsorolt kategóriák közül azt kellett kiválasztania, amely kategória szerinti intervallumba az életkora beletartozott.) A kérdőív összeállítása során 6 csoportot különböztettem meg: 18-21 életév, 21-31 életév, 31-41 életév, 41-51 életév, 51-61 életév között, valamint 61 év felett.

A megkérdezettek közül 5 fö a 18-21, 16 fö a 21-31, 26 fö a 31-41, 3 fö pedig a 41-51 közötti életkori kategóriába tartozott. 51-61 életév közötti, valamint a feletti személyt a kutatásba nem vontam be. A minimumérték a 41-51 életév, a maximumérték pedig a 31-41 életév közötti kategóriákat ölelte fel, 6 és 52\%-kal. A skálázó értékek miatt az országos életkori statisztikai rendszerrel sem tudtam az adatokat összevetni. Meg kívánom viszont jegyezni, hogy a kutatás önmagában a legszigorúbb anonimitást követte, ezért kerültek az életkornál is skálázó értékek meghatározásra, és nem konkretizálva az egyes életkori tényezőket. Ugyanez igaz a rendőrség létszámadataira is. A fentieket az alábbi grafikonon illusztrálom (1. ábra).

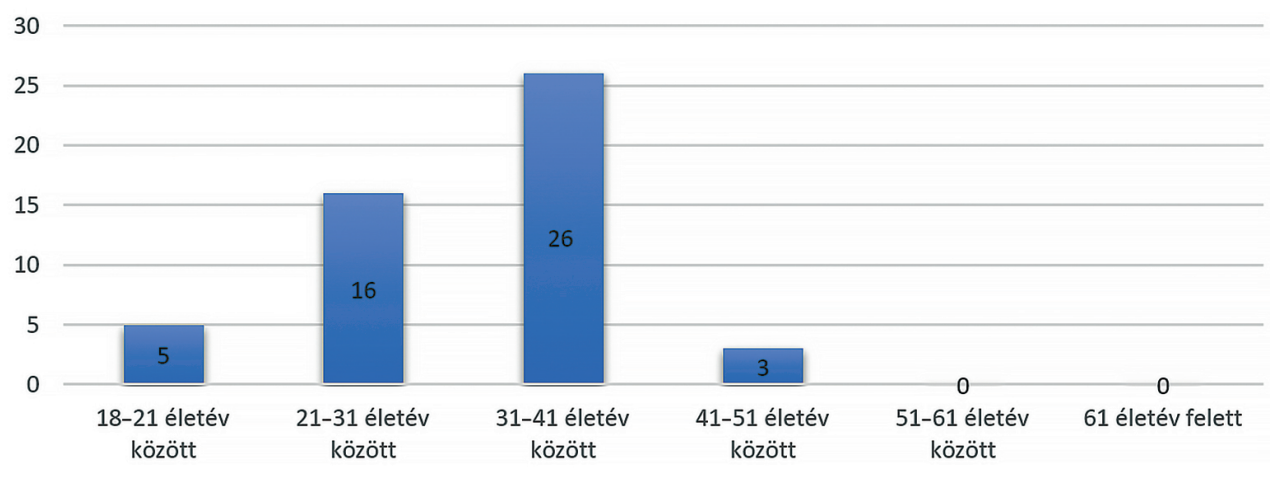

1. ábra: Az életkor.

Forrás: a szerző szerkesztése

\section{A nemi identitás}

A feltett kérdés a résztvevő társadalmi nemének meghatározására vonatkozott. (A résztvevőnek a felsorolt kategóriák közül azt kellett kiválasztania, amely jelenleg a társadalmi nemét jellemezte. Függetlenül attól, hogy születéskor milyen nemüként sorolták be.) 3 csoportot különböztettem meg, férfi, nö, transznemü. 
A nem mint független változó a kutatások fontos alappillére, ahogy jelen tanulmányban is. ${ }^{14} \mathrm{~A}$ kutatás során a felmérésben a megkérdezettek magukat kizárólag női és férfi nemi identitásúnak vallották, a férfiak $86 \%$-ot, a nők pedig $14 \%$-ot tettek ki, az arány 43 férfi és 7 nő között oszlott meg. A hatósági nyilvántartásokkal az adatokat nem tudtam összevetni, azonban a Központi Statisztikai Hivatal 2019ben a magyar népesség női és férfi arányát 47-53\%-ban határozta meg. ${ }^{15} \mathrm{~A} 4675$ 821 nőhöz viszonyítva a felmérésben részt vevő 7 fö; valamint az 5096935 férfihez viszonyítva a felmérésben részt vevő 43 fő elenyésző. A fentieket az alábbi grafikon szemlélteti (2. ábra).

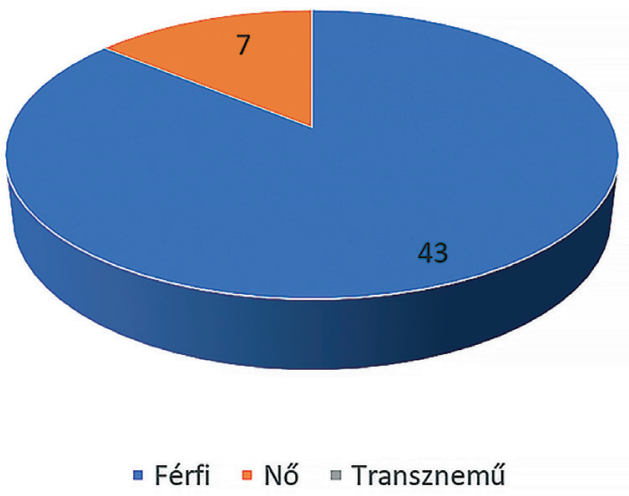

2. ábra: Nemi identitás.

Forrás: a szerző szerkesztése

\section{Legmagasabb iskolai végzettség}

A feltett kérdés a résztvevő befejezett tanulmányi végzettségének és/vagy végzettségeinek, képesítésének és/vagy képesítéseinek megismerésére irányult. (A résztvevőnek a felsorolt kategóriák közül azt és/vagy azokat kellett kiválasztania, amely az elvégzett/befejezett tanulmánya és/vagy tanulmányainak meglétét igazolta.) Hét kategóriát különböztettem meg: kevesebb, mint 8 általános, 8 általános, érettségi (gimnázium), felsőfokú (OKJ-tanfolyam), felsőfokú (BSc., főiskola), felsőfokú (MSc., egyetem), felsőfokú (PhD., posztgraduális).

A megkérdezettek vonatkozásában 17 fő érettségi, 11 fő felsőfokú (OKJ-) bizonyítvánnyal, 16 fö BSc, 6 fö pedig MSc diplomával rendelkezett. A minimumérték 12\%kal az egyetemi, a maximumérték 34\%-kal a középfokú végzettség között mozgott. A személyes körülmények első részszegmenshez tartozó eredménye, hogy a végrehajtói

14 Ürmösné Simon Gabriella: Egynyelvüek kommunikációja a nemek tükrében. In Fülöp Péter (szerk.): Spring Wind konferenciakötet 2012. Budapest, Doktoranduszok Országos Szövetsége. 2012.

15 Népesség, népmozgalom. Központi Statisztikai Hivatal Elérhető: www.ksh.hu/docs/hun/xstadat/xstadat_eves/i_wnt001a.html (A letöltés dátuma: 2020. 05. 10.) 
állományban 22 fö, azaz 44\% felsőfokú végzettséggel, diplomával rendelkezett. Ez arra enged következtetni, hogy szakirányú végzettség esetében vezetéstudományt mint elméleti tézist a felsőoktatásban tanult. (Civil diploma esetén is kaphatott ilyen jellegű képzést, azonban erre információm nincs.) Így válik hitelessé a kutatásban részt vevők véleménynyilvánítása. A fentieket az alábbi grafikonon illusztrálom (3. ábra).

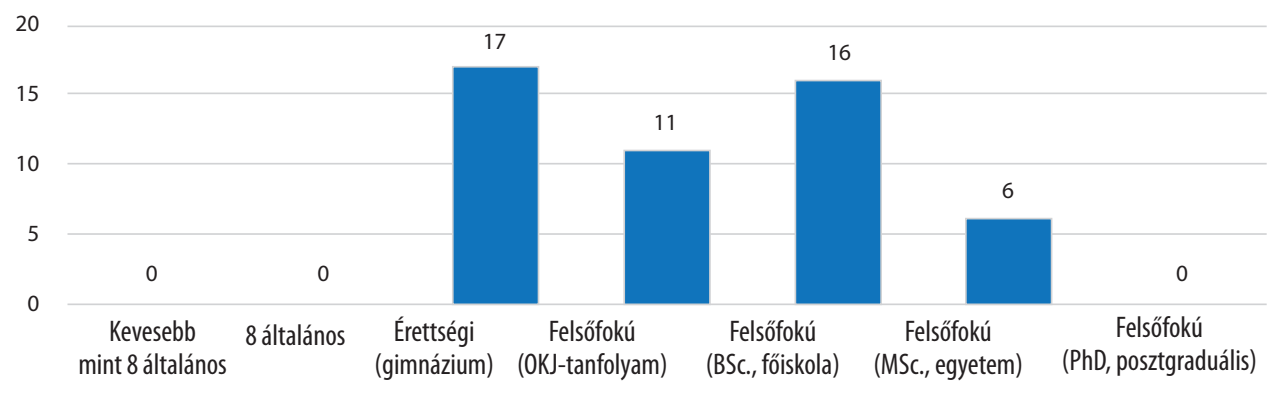

3. ábra: Legmagasabb iskolai végzettség.

Forrás: a szerző szerkesztése

\subsection{Munkakörnyezet}

A második blokk a kitöltők munkakörnyezetének megismerésére irányult. A felmérés e fejezetében összesen 15 kérdést tettem fel, amelyek közül 10 egyszerü zárt láncú, 3 numerikus és 2 rendezetlen kérdés kapott helyet. A kérdések között e szegmensnél a munkavégzés helyszíne, a szolgálati ág és a munkaviszony időtartama szerepelt. (Ugyanakkor más tárgykörök is ismertetésre kerülhetnek, de a vezetési stílusokkal összefüggésben e kérdéseknek van meghatározó jelentőségük.) A fentiekből az alábbi eredmények születtek.

\section{A munkavégzés helyszíne}

A feltett kérdés annak megválaszolására irányult, hogy a felmérésben részt vevő a rendőri szerv melyik egységénél teljesít szolgálatot. Három kategóriát különböztettem meg, amelyekből a válaszadók kizárólag egy kategóriát jelölhettek meg: helyi rendvédelmi szerv, központi rendvédelmi szerv és területi rendvédelmi szerv.

A megkérdezettek közül 21 fö (42\%) helyi, 28 fö (56\%) központi és mindösszesen 1 fö $(2 \%)$ területi szervnél teljesített szolgálatot. A minimumérték a területi, a maximumérték pedig a rendőrség központi szerveinél tetőzött. Ugyan különbséget nem tehetünk a között, hogy a hivatásos állomány tagja a rendörség mely szolgálati egységénél teljesít szolgálatot, de alátámasztást nyert, hogy sokkal inkább dominánsabb azon válaszadók száma, akik a központi egységeknél dolgoznak. A fentieket az alábbi grafikon szemlélteti (4. ábra). 


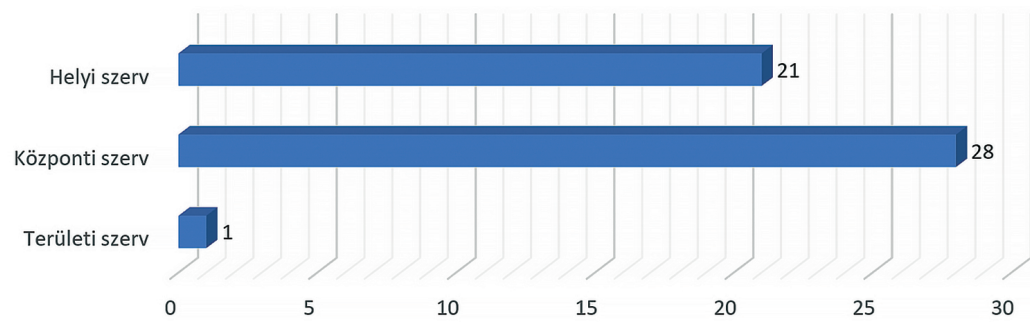

4. ábra: A munkavégzés helyszíne.

Forrás: a szerző szerkesztése

\section{Szolgálati ág tagozódása}

A feltett kérdés annak megismerésére irányult hogy a válaszadók a rendőrségen belül milyen szolgálati ágnál teljesítenek szolgálatot. A kérdőívet kitöltők mindösszesen kettő kategória közül választhattak, amely vonatkozásában csak egyet jelölhettek meg: bűnügyi szolgálati ág, rendészeti szolgálati ág.

A felmérést kitöltők a rendészeti és bủnügyi szolgálati ág állományát erősítették. A bűnügyi szolgálati ág a kitöltők $60 \%$-át, míg a rendészeti a $40 \%$-át ölelte fel. A kettő érték közötti differencia mértéke 10\% volt. A felmérésben 10\%-kal több bűnügyes töltötte ki a kérdőíveket, mint a rendészeti szakterületen dolgozók közül. A 20 rendész közül 19 helyi szervnél teljesített szolgálatot, ami a megkérdezettek 95\%-át ölelte fel, 1 fö, azaz 5\% a területi szervnél munkálkodott. Ugyanezen adatok összehasonlítva a 30 fő bünügyes közül 28 fő központi és mindösszesen 2 fö helyi dolgozott csak helyi szervnél. Az arányokat tekintve az 94-6\% között mozgott. Sokkal inkább domináns tehát a bünügyi vénával rendelkezők létszáma, mint a rendészeti állományé. (Nincs differenciálódás a között, hogy a bủnügyi szolgálati ág vagy a rendészeti szolgálati ág vonatkozásában milyen beosztást töltenek be a felmérés résztvevői. A nyílt és operatív területen foglalkoztatottak között sem állítottam fel különbségi kategorizálást, ugyancsak az utcai vagy a rendészethez kapcsolódó bünmegelőzéssel foglalkozó szakemberek között sem.) A fentieket az alábbi grafikonon szemléltetem (5. ábra).

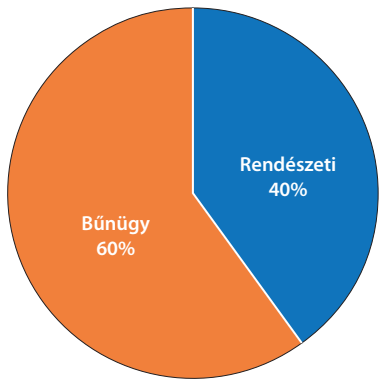

5. ábra: A szolgálati ág tagozódása. 


\section{A munkaviszony időtartama}

A feltett kérdés során azt vizsgáltam, hogy a kérdőívet kitöltők hány éve dolgoznak a rendőrség kötelékében hivatásos állományú tagként. Az anonimitás megtartására tekintettel kizárólag év közti bontásokban adtam meg a szolgálati jogviszony időtartamát, így hat különböző kategóriát állítottam fel, amelyből a résztvevők csupán egyet jelölhettek meg: 0-2 év, 2-4 év, 4-6 év, 6-8 év, 8-10 év, 10 év felett.

A munkaviszony időtartamából választ kaptam rá, hogy 1-1 fő 2-4 év, illetve 4-6 év közötti, 28 fő 6-8 év, 20 fő 8-10 év közötti hivatásos szolgálati viszonnyal rendelkezik, de a megkérdezettek között olyan nem volt, aki ezt meghaladta volna. A minimumérték így $2-2 \%$, a maximumérték pedig $56 \%$ volt. Mindezek ellenére megállapítható, hogy a maximumérték, azaz a 28 fő a $6-8$ év szolgálati viszonyával fiatal munkavállalónak tekinthetö, amelytől csak 29\%-kal marad el a szintén fiatal munkavállalónak tekinthető 8-10 éves munkaviszonyciklus. Veterán vagy idősebb munkavállaló a megkérdezettek között nem volt. A 28 fő mindegyike bủnügyi területen dolgozott, a valamivel, 2-4 évvel több munkaviszonyi kategória, azaz a 20 fö pedig a rendészeti állományt erősítette. A fentiek alapján megpróbáltam párhuzamot vonni a tekintetben, hogy a szolgálati jogviszony éveinek száma egyenesen arányos-e az életkori jellemzőkkel, azonban az nem minden esetben esett egybe. Ennek magyarázatát az adja, hogy hiába rendelkezik valaki x év szolgálati jogviszonnyal, közel sem behatárolható, hogy hivatásos szolgálati jogviszonyát a törvény erejénél fogva akár 18 vagy akár 21 évesen kezdené meg, vagy nem a felső korhatár be nem töltésével jelentkezne hivatásos szolgálati jogviszony létesítésére. E kérdéskörben csak arra kaphattam választ, hogy valójában mennyi a résztvevők hivatásos szolgálati jogviszonyának időtartama. A fentieket az alábbi grafikon szemlélteti (6. ábra).

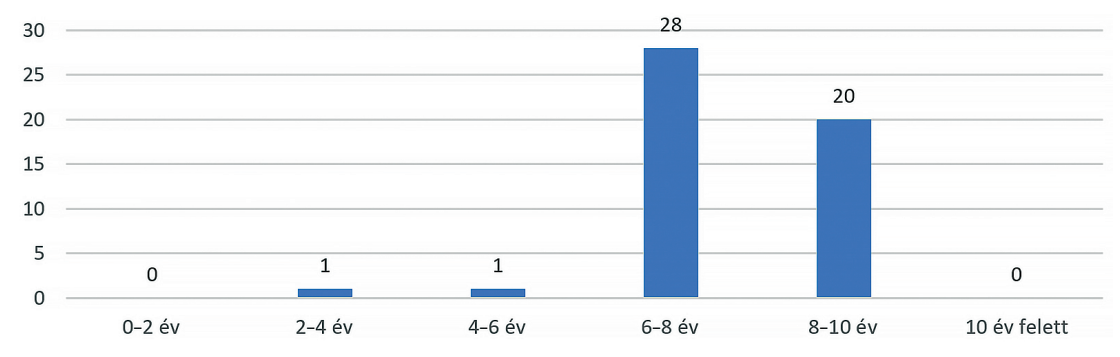

6. ábra: A munkaviszony idótartama.

Forrás: a szerző szerkesztése

\subsection{Vezetési rendszerek}

A harmadik blokk a vezetési rendszerek megismerésére irányult. A felmérés e fejezetében összesen 15 kérdést tettem fel, amely 8 zárt, 3 numerikus, 4 rendezetlen kérdést tartalmazott. A kérdések között e szegmensnél a vezetési stílusok, a szervezeti egység, eredményesség, a változtatás szükségessége, a vezetői magatartás prioritása, saját ambíciók és az önkritika került előtérbe. 


\section{Vezetési stílusok alkalmatossága a Rendörségen}

A feltett kérdés annak megválaszolására irányult, hogy a válaszadók szerint a rendőrség vezetésére melyik stílus lenne a legalkalmasabb. A Lewin-féle tipológiai szerint három kategória közül választhattak a résztvevők, amelyek közül kizárólag csak egyet jelölhettek meg: demokratikus, autokratikus, laissez-faire.

30 fö, azaz a válaszadók 60\%-a (a maximumértéket képviselve) a demokratikus vezetési stílus mellett voksolt. Az autokrata csupán $14 \%$-ot (7 fö), a ráhagyó pedig $26 \%$-ot (13 fö) ért el. A felmérésben részt vevők a vezetési stílusok közül a rendőrség vonatkozásában az autokrata vezetési stílust tartják a legalkalmatlanabbnak, míg a demokratikust a legalkalmasabbnak. Meglepö módon a ráhagyó vezetési stílus a voksok tekintetében valamivel kevesebb, mint a demokrata felét és valamivel több, mint az autokrata dupláját kapta. Ezzel a résztvevők alátámasztották, hogy a laissez-faire vezetési stílus sokkal alkalmatosabb, mint az autokrata vezetési stílus, de kevésbé olyan alkalmatos, mint a demokrata vezetés. A fentieket az alábbi grafikonon illusztrálom (7. ábra).

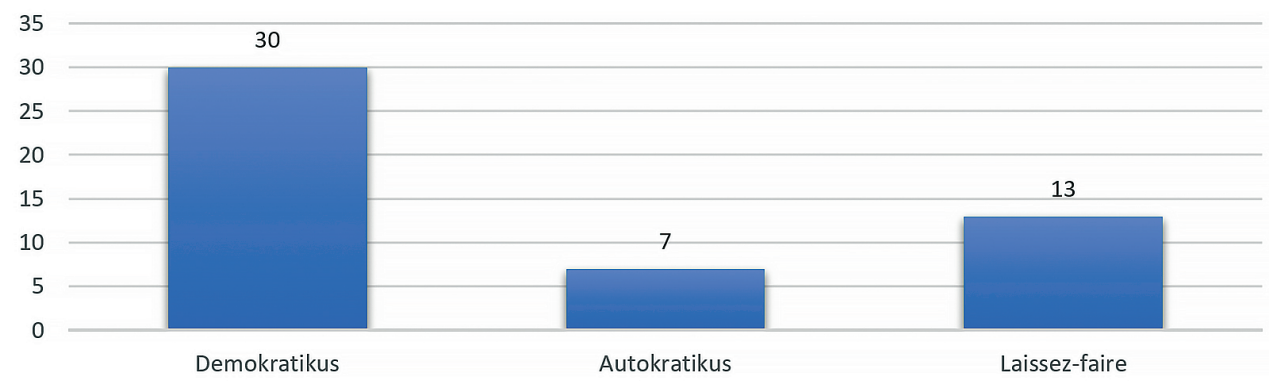

7. ábra: Vezetési stílusok alkalmatossága a Rendörségen.

Forrás: a szerző szerkesztése

\section{Vezetési stílusok a szervezeti egységekben}

Ellentétben az előzőkkel e kérdés annak megválaszolására irányult, hogy a szervezeti egységek vezetői a felmérésben részt vevőkkel szemben milyen stílust gyakorolnak. A kategóriákat szintén a Lewin-féle tipológia ${ }^{16}$ szerint vázoltam, amelyek közül a válaszadók csak egy kategóriát jelölhettek meg: autokratikus, demokratikus, laissez-faire.

A ráhagyó vezetési stílus a minimumértéket képviselte, mindösszesen $6 \%$-ot ért el. Az autokrata és a demokratikus fej-fej mellett haladva 50 és $44 \%$-ot képviselt. A helyi, központi és területi egységek tekintetében az autokrata vezetési stílus dominál, annak ellenére, hogy az állomány a demokratikus stílust tartja a legalkalmasabbnak a szervezet vezetésére. A válaszadók közül 7 fö helyi, míg 18 fö pedig központi területen dolgozott. A szolgálati ág tagozódása szerint 15 bűnügyes és 10 közrendes

16 Ürmösné Simon Gabriella: Hungarian - Greek Communicative Strategies in Respect of Gender. In Mental procedures in language processing. Studies in Psycholinguistics 3. Budapest, Tinta, 2012. 280-290. 
kolléga gondolta úgy, hogy szolgálati helyükön autokrata vezetési stílust gyakorolnak. A felsőfokú végzettséggel rendelkezők aránya $32 \%$ volt, azaz elméleti és gyakorlati szinten is ismerte az autokrata fogalom megfelelőjét. A kettő közti korreláció mértéke $+1,14$ volt, amely tökéletesen pozitív és nagy. A laissez-faire vonatkozásában a $6 \%$, azaz a három válaszadó közül 2 helyi szervnél dolgozott és 8-10 éves tapasztalattal, 1 pedig központi szervnél látott el szolgálatot és 6-8 év szakmai tapasztalattal rendelkezett. Ahhoz képest, hogy a válaszadók véleménye szerint a laissez-faire vezetési stílus sokkal inkább alkalmasabb, mint az autokrata vezetési stílus a rendőri szervek vezetésének vonatkozásában, mégis a szervezeti egységekben az autokrata vezetés dominál. Ez a vezető jellemével is összefügg. ${ }^{17} \mathrm{~A}$ fentieket az alábbi grafikon szemlélteti (8. ábra).

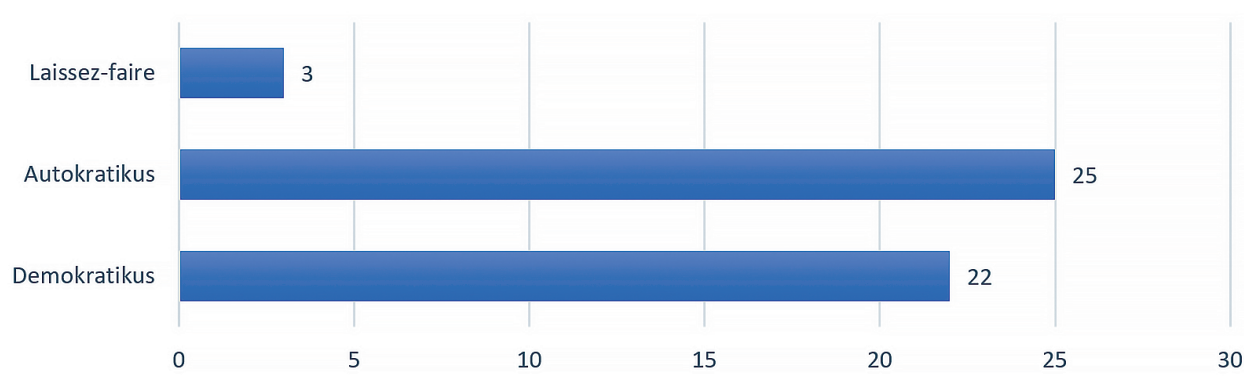

8. ábra: Vezetési stilusok a szervezeti egységekben.

Forrás: a szerző szerkesztése

\section{Egyet- vagy egyet nem értés a vezetői stílussal}

A fenti kérdés annak megválaszolására irányult, hogy a szervezeti egységekben gyakorolt vezetési stílussal a válaszadók egyetértenek-e, vagy sem, azt milyen mértékben teszik. Két kategóriát állítottam fel: igen vagy nem.

A felmérést kitöltők közül 27 fő nem és 23 fö értett egyet azzal, hogy helyes a szervezeti egységek vezetőinek vezetési stílusa. Arányaiban ez a válaszadók 54 és $56 \%$-a. Nincs nagy eltérés az egyet és az egyet nem értés között, mégis a maximumérték vonatkozásában a nem ért egyet válaszadás dominált. A statisztikai elemzést kiterjesztettem a vonatkozásban is, hogy a 27 fö, akik nem értenek egyet a szolgálati helyük vezetési stílusaival, azok közül mennyien gyakorolnának inkább laissez-faire vezetési stílust. Mindezek közül 13 fő a laissez-faire-, míg 14 fő a demokrata vezetési stílust tartja meggyőzőnek a rendőri szervek vezetésére. Függetlenül attól, hogy demokrata vagy ráhagyó stílust választottak a kérdőívet kitöltők, a szolgálati helyen alkalmazott vezetési stílussal - amelynek dominanciája az autokrata vezetési felé hajaz - nem értenek egyet. A fentieket az alábbi grafikon szemlélteti (9. ábra).

17 Szabó Csaba: Examination About the Law Enforcement Strategies which are Influence the Criminal Behaviour. AARMS, 15. (2016), 3. 263-269. 


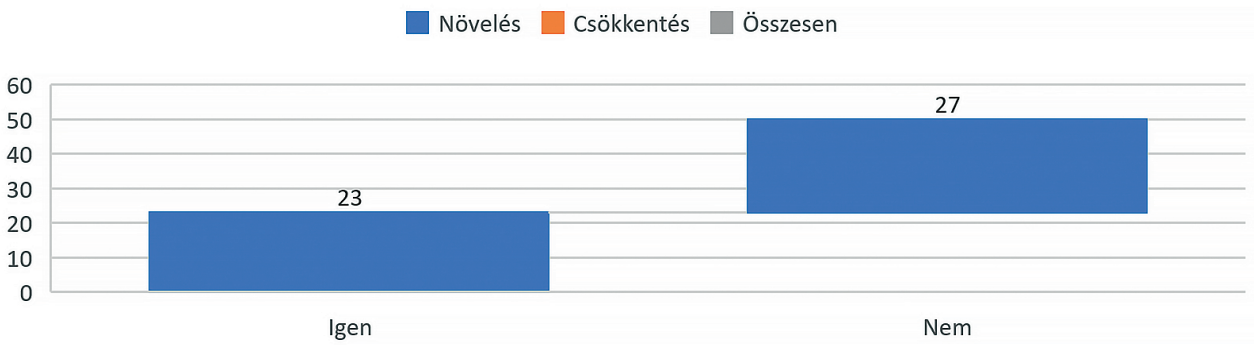

9. ábra: Egyet- vagy egyet nem értés a vezetői stílussal.

Forrás: a szerző szerkesztése

\section{A vezetöi magatartás prioritása}

A feltett kérdésből megtudatjuk, hogy a válaszadók szerint a szervezeti egységek vezetői a szakmai feladatok elvégzésére vagy a beosztotti állomány humán eredetű támogatására koncentrálnak igazán. Két kategóriát állítottam fel: szakmai feladatok elvégzése, beosztotti állomány humán eredetű támogatása. A válaszadók e két tevékenységet rangsorolhatták, és sorrendet állíthattak fel.

A humán eredetű vezetői támogatás mindösszesen csak 15 esetben szerepelt első helyen, 35 helyen második volt. A szakmai feladatok elvégzése logikailag ennek inverzére épült. A ráhagyó vezetési stílus vonatkozásában 6 esetben a humán eredetű támogatás volt az első helyen, és 7 esetben pedig ugyanúgy a szakmai feladatok elvégzése. E különbség inkább abban nyilvánul meg, hogy a szakmai feladatok elvégzésében a laissez-faire vezetési stílus nagyobb önállóságot enged meg a végrehajtás tekintetében, így a vezetőnek több ideje van az esetleges humán eredetü problémák kezelésére és támogatására. A fentieket az alábbi grafikon szemlélteti (10. ábra).

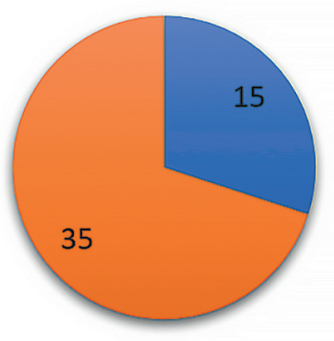

Szakmai feladatok elvégzése
Beosztotti állomány humán eredetű támogatása 


\section{Eredményesség a vezetői munka tükrében}

A fenti kérdés annak megválaszolására irányul, hogy a szolgálati helyeken alkalmazott vezetési stílus vajon eredményes-e a válaszadók szerint. Két kategóriát állítottam fel: igen vagy nem, amelyek közül a válaszadók csak egy kategóriát jelölhettek meg.

Választ kaptunk arra a kérdésre, hogy a felmérést kitöltő állomány vonatkozásában, a szolgálati helyeken a ráhagyó vezetési stílus a minimumértéket képviselte, mindösszesen $6 \%$-ot ért el. Az autokrata és a demokratikus fej-fej mellett haladva 50 és $44 \%$-ot képviselt. A fentiekkel összefüggésben a vizsgálatba bevont állomány több mint a fele, 58\%-a véli úgy, hogy az alkalmazott vezetői stílus nem hoz eredményt. A fentieket az alábbi grafikon szemlélteti (11. ábra).

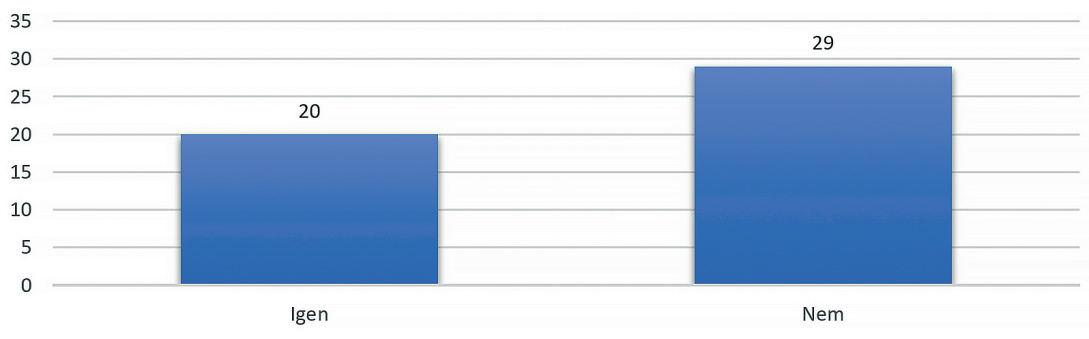

11. ábra: Eredményesség a vezetöi munka tükrében.

Forrás: a szerző szerkesztése

\section{Vezetési stílus megváltoztatása}

A fenti kérdés annak megválaszolására irányult, hogy a szolgálati helyeken alkalmazott vezetési stílus megváltoztatása szükséges-e, vagy sem. A válaszadók két kategória közül választhattak, amelynek során csak egyet jelölhettek meg: igen vagy nem.

A válaszadók jelentős része, $68 \%$-a az igen szavazat mellett voksolt. $32 \%$ vélte csak úgy, hogy a vezetési stílust nem szükséges megváltoztatni. Azok, akik a laissez-faire vezetési stílust mint a szervezeti egység uralkodó vezetési stílusát választották, a vezetési stílust nem szerették volna megváltoztatni. A fentieket az alábbi grafikonon illusztrálom (12. ábra).

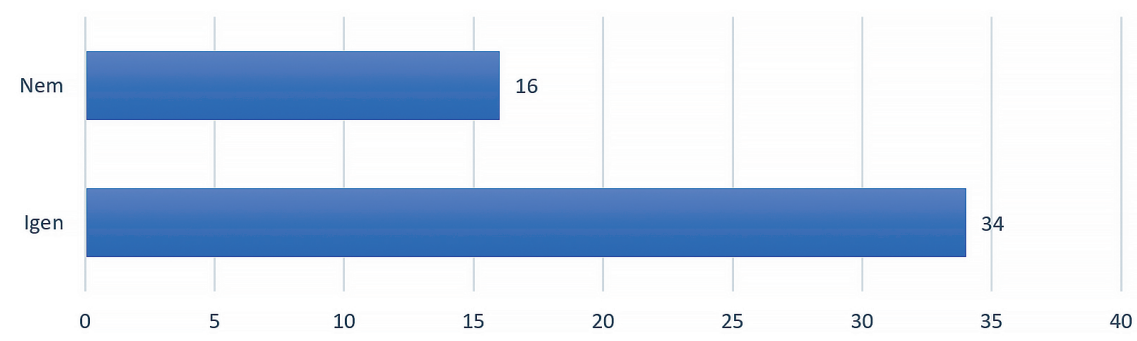

12. ábra: Vezetési stílus megváltoztatása. 


\section{„Ön jobban csinálná?"}

A feltett kérdés annak megválaszolására irányult, hogy vajon a felmérésben részt vevő véleménye szerint, ha lehetősége lenne rá, akkor jobban vezetné-e a szervezeti egységet, mint amelyben most dolgozik. Két kategóriát állítottam fel: igen vagy nem, amelyek közül a válaszadók csak egyet választhattak ki.

A feltett kérdés önkritika gyakorlására buzdította a résztvevőket. A jelenségek kritizálására irányuló elmélkedés csak akkor lehet eredményes, ha az konstruktív jellegü, és a problémára megoldást is javasol. A válaszadók közül 34 fő, azaz $68 \%$ úgy vélte, hogy képes lenne jobban vezetni a szervezeti egységet, mint a jelenlegi vezetői. Ez a szám korrelál azokkal, akik demokrata stílusban szeretnének vezetni, és autokrata vezetés alatt teljesítenek szolgálatot, (50\%), valamint álláspontjuk szerint a vezetés eredménytelen (58\%). A laissez-faire vonatkozásában nemleges választ kaptam, a munkavállalók elégedettek. A fentieket az alábbi grafikon szemlélteti (13. ábra).

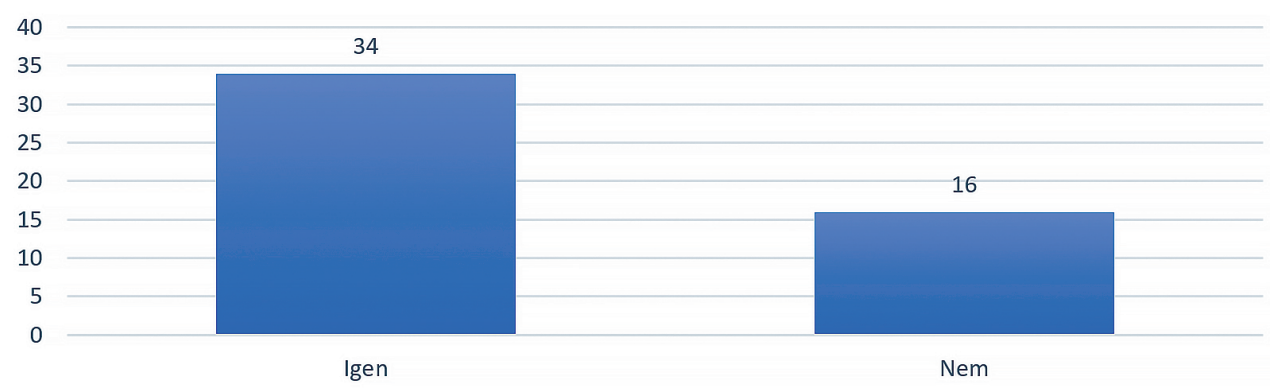

13. ábra: Az „Ön jobban csinálná?” kérdésre adott válaszok.

Forrás: a szerző szerkesztése

\section{Vezetői ambíció}

A feltett kérdés annak megválaszolására irányult, hogy a válaszadók rendelkeznek-e vezetői ambíciókkal jelenlegi beosztásukat követően. A feltett kérdés vonatkozásában két kategóriát állítottam fel, a résztvevők a közül egyet voltak kötelesek kiválasztani: igen vagy nem.

A válaszadók több mint fele, 58\%-a rendelkezett vezetői ambíciókkal. E kör megegyezett azzal, akik az elöző kérdésre is igennel feleltek. 42\% a későbbiekben is a végrehajtói állományt erősítené. Azok között, akik vezetői pozíciót vállalnának, 18 fő felsőfokú végzettséggel rendelkezik a 22 fős BSc- és MSc-diplomával rendelkezők arányából, amely $81 \%$-ot jelent. A vezetőkkel szemben támasztott kritériumrendszert, amely felsőfokú végzettség meglétét írja elő, e személyek teljesítették. Reális lehetőségük arra, hogy vezetői pozíciót töltsenek be e szempontból érvényesült. A fentieket az alábbi grafikonon illusztrálom (14. ábra). 


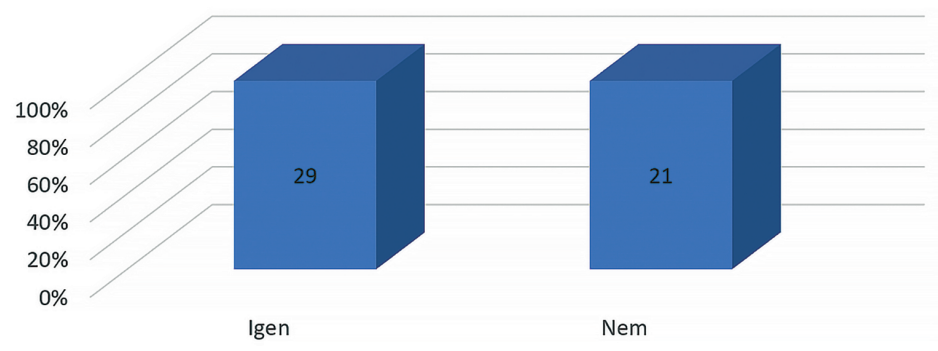

14. ábra: Vezetői ambíció.

Forrás: a szerző szerkesztése

\section{4. Összegzések, következtetések}

A közszférába, az állami szervek müködésébe vetett társadalmi bizalom emberi életek sokaságát befolyásolja. A bűnözés nem ismer - sem elvi, sem fizikális - határokat, így az állam olyan kormányzati politikát köteles folytatni, amely szükség esetén beavatkozik, a területén élő közösségek életét megvédi, vallott értékeit tiszteletben tartja, az ország külső és belső védelmét megteremti, a fenyegetésekkel és veszélyekkel szembeni biztonságot garantálja. Mindez elérhető a védelmi szervek olyan irányításával, amely az európai uniós tendenciákkal összhangban rátermettségével, kreativitásával és professzionális beavatkozási képességeivel a problémák megelőzésére, megszakítására és megszüntetésére alkalmas. A dualizmuskori "haza, és haladás" mottóját a 21. században a rendvédelmi szervek körében a "személy, biztonság és integritás" szolgáltatása egészítette ki. A kiadott feladatok viszont csak úgy érvényesíthetők, ha a rendőrök a napi feladataikat szigorúan a jogszabályok betartásával hajtják végre. Hogy ezen feladatok végrehajtására a rendőri vezető milyen vezetési stílust alkalmaz, nagyon nagy heterogenitást tükröz, amely jól körvonalazódik a kutatásban is. A primer forrás mindig a személyes kompetencia, azaz a személy beosztásra való alkalmatossága. „Megfelelő embert, a megfelelő helyre." Vagyis mind a szervezet, mind az érintett személy akkor jár a legjobban, ha a rászabott munkakörben dolgozhat. ${ }^{18}$ Ebböl adódóan nem minden ember alkalmas minden pozíció betöltésére, egyik szakági területen sem. ${ }^{19}$ Azt is kijelenthetjük, hogy a vezető személye, vezetői stílusa, szakmai felkészültsége nagyban befolyásolja a munkaerő megtartását egy-egy szervezet esetében. ${ }^{20}$

Annak ellenére, hogy a felmérés nem reprezentatív, mégis jól látható, hogy a laissez-faire vezetési stílus, ha nem is nagy esetszámban, de a rendőri vezetésben éppen úgy jelen van, mint a demokrata vagy az autokrata vezetési stílus.

18 Szakács Gábor: A szervezeti kultúra, a szervezeti hatalom a rendvédelmi szerveknél. In Horváth József - Kovács Gábor (szerk.): Rendészeti szervek vezetés- és szervezéselmélete. Nemzeti Közszolgálati Egyetem, 2014.

19 Szabó Csaba: A 3D nyomtatási technológiával előállított tủzfegyverek biztonságpolitikai kihívásainak vizsgálata a fegyverrendészet aspektusából II. Nemzetbiztonsági Szemle, (2017), 4. 110-124.

20 Vö.: Magasvári Adrienn - Szabó Andrea: A Nemzeti Adó- és Vámhivatal munkaerő-megtartó képességének vizsgálata egy speciális célcsoport tükrében. Magyar Rendészet, 19. (2019), 2-3. 143-162. 
Alátámasztást nyert az is, hogy a beosztotti állomány sokkal inkább előrébb sorolja a ráhagyó vezetési stílust, mint az autokratát, de a demokrata stílust az megelőzni nem képes. Ebből következésképpen az állapítható meg, hogy az állománynak szüksége van a parancsnoki iránymutatásra, de közel sem mindegy, hogy az milyen mértékü és minőségü. Bizonyítottá vált az is, hogy amennyiben a vezetési stílusok közül a laissez-faire használatra kerül, úgy az illetékes rendőri vezető sokkal inkább tud az állomány humán eredetű gondjaira és megoldandó feladataira koncentrálni, mint a szakmai feladatokra, hiszen ott az önállóságot megkapják. A parancsnok a figyelmét úgy képes osztani, hogy a szakmai eredetű feladatok is el legyenek végezve és az állomány humán eredetü gondjai is megoldásra találhatnak.

A ráhagyó stílus alkalmazásakor a motiváció is növelhetö, hiszen az egyén kibontakozódhat, nem szorítják keretbe, amelyen belül korlátozottan cselekedhet. Természetesen ez a láthatatlan keret nem vonatkozik a szigorú normakontrollra, hiszen azon felül egyik vezetési stílus és az alkalmazott intézkedések sem terjeszkedhetnek túl. Ez a motiváció kiváló szakértelemmel és készségekkel rendelkező csapatok számára előnyt kovácsolhat, hiszen a kreatív csapatok mindig értékelik a függetlenséget. Figyelni szükséges viszont arra, hogy a ráhagyó stílus csak akkor müködhet jól, ha a vezető a projekt elején megadja a szükséges információkat és anyagokat a munkavégzéshez, amelyből az állomány dolgozni tud. Ugyanez realizálódik a hátrányokban is, hiszen a függetlenség és szabadelvűség kontroll nélkül határidő-mulasztáshoz vezethet, amely a rendvédelmi szervek vonatkozásában rossz teljesítményben tetőzik, így sérül a bünözés elleni harc eredményessége.

A laissez-faire vezetői stílus egy szervezetben teljes szabadságot és hatalmat enged a munkavállalóknak, motiválja a végrehajtói és vezetői állományt a munkavégzésre úgy, hogy a szervezeti céloknak leginkább megfeleljenek. Ez a fajta szabadságérzet - vezetői kontroll bizonyos hiánya - pozitívan befolyásolja a munkájukat, amelynek eredménye, hogy támogató csapatként fognak dolgozni, a végtermék pedig az innovációban, a magas teljesítményben és a szervezet növekedésében érhető tetten. A rendőri vezetésnek is el kell gondolkodnia azon, hogy érdemes-e beépíteni a laissez-faire vezetési stílust a végrehajtásba, hiszen a kreativitás előrevetítheti az eredményességet, egyfajta bizalmul is szolgál, így csökkenthető a hatalmi távolság indexe, nagyobb koncentrációt kap a szakmai feladatok elvégzése mellett a munkavállaló humán eredetủ támogatása is. A vezető felelőssége, hogy mely vezetési stílust alkalmazza, és milyen arányban enged teret a szakmai feladatok és az állományról való gondoskodás kibontakozásában.

\section{Felhasznált irodalom}

Beer, Stafford: Decision and Control. Chichester, Wiley, 1966.

Deák József: The Police, then Interior Review for the Forming of the Science of Law Enforcement; from its Beginning to the Change of the Political System. West Bohemian Historical Review, 4. (2014), 2. 237-254.

Deák József: A tudomány szabadsága, politikai és hierarchikus hatások régen és ma a Belügyi Szemlében. Pécsi Határör Tudományos Közlemények, 17. (2016), 271-276. 
Dragon Sándor: Nyilas rendvédelem - tények, tapasztalatok, következtetések. Zsidó sorsok a nyilas időszakban címü konferencia a kutatók éjszakáján 2019. szeptember 27. Budapest, Holokauszt Emlékközpont, 2019.

Dragon Sándor: A rendészettudomány hatása, alkalmazása és fejlődésének lehetőségei a rendészeti szervek gyakorlati vezetésében, irányításában. Rendörségi Tanulmányok, 2. (2019), 3. 86-98.

Eagly, Alice - Mary C. Johannesen-Schmidt - Marloes L. van Engen: Transformational, Transactional, and Laissez-Faire Leadership Styles: A Meta-analysis Comparing Women and Men. Psychological Bulletin, 124. (2003), 4. 569-591. DOI: https:// doi.org/10.1037/0033-2909.129.4.569

Koontz, Dean: Management: A Book of Readings. McGraw-Hill, 1959.

Kovács Gábor - Czuprák Ottó: A szervezetvezetés elmélete. Budapest, Dialóg Campus, 2017.

Kovács Gábor: A rendészeti szervekben lejátszódó folyamatok. In Kovács Gábor - Horváth József (szerk.): Rendészeti szervek vezetés- és szervezéselmélete. Nemzeti Közszolgálati Egyetem, 2014. 57-92.

Kovács István: Vezetési funkciók egy helyi rendvédelmi szerv életében. Ellenőrzés, mint a kiadott szabályok, és utasítások betartásának (kontroll)feladata. Államtudományi Mühelytanulmányok, (2017), 21. 1-30.

Lewin, Kurt - Fritz Heider - Grace Heider: Principles of Topological Psychology. New York, Mcgraw Hill, 1936. DOI: https://doi.org/10.1037/10019-000

Magasvári Adrienn - Szabó Andrea: A Nemzeti Adó- és Vámhivatal munkaerő-megtartó képességének vizsgálata egy speciális célcsoport tükrében. Magyar Rendészet, 19. (2019), 2-3. 143-162. DOI: https://doi.org/10.32577/ mr.2019.2-3.8

Northouse, Peter: Leadership: Theory and Practice. Thousand Oaks, Sage, 2006.

Piros Attila: Gondolatok a vezetésről, a parancsnoki munkáról. Magyar Rendészet, 17. (2017), 4. 177-191.

Szabó Csaba: A 3D nyomtatási technológiával előállított tűzfegyverek biztonságpolitikai kihívásainak vizsgálata a fegyverrendészet aspektusából II. Nemzetbiztonsági Szemle, 5. (2017), 4. 110-124.

Szabó Csaba: Examination About the Law Enforcement Strategies which are Influence the Criminal Behaviour. AARMS, (2016), 3. 263-269.

Szakács Gábor: A szervezeti kultúra, a szervezeti hatalom a rendvédelmi szerveknél. In Horváth József - Kovács Gábor (szerk.): Rendészeti szervek vezetés- és szervezéselmélete. Nemzeti Közszolgálati Egyetem, 2014.

Ürmösné Simon Gabriella: Egynyelvüek kommunikációja a nemek tükrében. In Fülöp Péter (szerk.): Spring Wind 2012 konferenciakötet. Budapest, Doktoranduszok Országos Szövetsége. 2012. 1-12.

Ürmösné Simon Gabriella: Hungarian-Greek Communicative Strategies in Respect of Gender. In Mental Procedures in Language Processing. Studies in Psycholinguistics 3. Budapest, Tinta, 2012. 


\section{Internetes forrás}

Népesség, népmozgalom. Központi Statisztikai Hivatal. Elérhető: www.ksh.hu/docs/ hun/xstadat/xstadat_eves/i_wnt001a.html (A letöltés dátuma: 2020. 05. 10.)

\section{Jogi forrás}

48/1991. (IX. 26.) számú AB határozat. Elérhető: http://public.mkab.hu/dev/dontesek. nsf/0/413887D00724A32FC1257ADA00529B43?OpenDocument (A letöltés dátuma: 2017. 11. 26.) 